\section{Effects of Reserpine, Serotonin and Vasopressin on the Survival of Cold-Stressed Rats}

In the preparatory stages of a projected study of the hypothalamic control of release of adrenocorticotrophic hormone, large doses of reserpine, serotonin creatinine sulphate, and commercial vasopressin were administered to rats which were then subjected to cold stress. Preliminary findings are reported here in view of the widespread interest in the drugs from the point of view of pituitary-adrenal physio$\log y^{1}$ and in view of the current extensive use of reserpine in medicine.

Intact male rats of the Harvard strain weighing 95-105 gm. were selected. All substances were administered subcutaneously, and cold-exposed controls received volumes of vehicle equal to those injected into the test animals. The rats were placed in individual screen-bottomed cages without food or water in a cold room at $3^{\circ} \pm 1^{\circ} \mathrm{C}$. either immediately following the injection, or in some cases $18 \mathrm{hr}$. after injection. To minimize variations due to cyclic changes in physiological activity the animals were placed in the cold room at approximately the same time (1200 midnight $\pm \frac{1}{2} \mathrm{hr}$.) except for one stressed control group which was exposed to cold starting at 11 a.m. Treated controls were kept at room temperature under otherwise similar conditions. For the sake of comparison a group of adrenalectomized animals ( 1 week after surgery) in the same weight range was similarly stressed. The results are summarized in Table 1 .

It is evident that large doses of reserpine, serotonin creatinine sulphate, and commercial vasopressin effectively lower the ability of intact rats to withstand cold stress, although on the basis of the experiments described here it is not possible to offer any demonstrable explanation for the mechanisms involved; however, the similarity in the survival-times of

Table 1. EFfects of Regerpine, Serotonin Creatinine SUlphate AND VASOPRESSIN ON THE SURVIVAL-TIMES OF COLD-STRESSED RATS

\begin{tabular}{|c|c|c|}
\hline Treatment & Survival time* & $\begin{array}{c}\text { No. of } \\
\text { animals }\end{array}$ \\
\hline $\begin{array}{l}1 \text { Intact controls, exposed at } 1200 \\
\text { midnight } \\
2 \text { Intact controls, exposed at } \\
11 \text { a.m. } \\
3 \text { Adrenaiectomized, untreated } \\
\text { animals } \\
42 \text { mgm. serotonin creatinine } \\
\text { sulphate, stressed immediately } \\
\text { after injection } \\
5 \text { mgm. serotonin creatine } \\
\text { sulphate, stressed immediately } \\
\text { after injection } \\
61 \text { mgm. serotonin creatinine } \\
\text { sulphate, stressed immediately } \\
\text { after injection } \\
72 \text { mgm, serotonin creatinine } \\
\text { sulphate, stressed } 18 \text { hr. after } \\
\text { injection } \\
81 \text { mgm. serotonin creatinine } \\
\text { sulphate, stressed } 18 \text { hr. after } \\
\text { injection } \\
9 \text { mgm. reserpine, stressed imme- } \\
\text { diately after injection } \\
10 \text { mgm, reserpine, stressed } 18 \text { hr. } \\
\text { after injection } \\
11 \text { units vasopressin, stressed im- } \\
\text { mediately after injection } \\
12 \text { units vasopressin, stressed im- } \\
\text { mediately after injection } \\
13 \text { units vasopressin, stressed } \\
14 \text { nr. after injection } \\
14 \text { units vasopressin, stressed } \\
18 \text { hr. after injection }\end{array}$ & 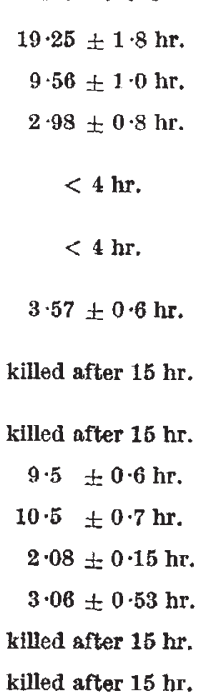 & $\begin{array}{r}20 \\
9 \\
9 \\
10\end{array}$ \\
\hline
\end{tabular}

All treated controls kept at room temperature survived for $24 \mathrm{hr}$. and were killed at that time.

* Mean \pm standard error of the mean. serotonin- and vasopressin-treated rats and the survival times of adrenalectomized animals suggests that treatment with these two drugs-both of which are known to exert some action on the pituitaryadrenal system ${ }^{1}$-results in temporary functional adrenalectomy.

Reserpine clearly differs from the other substances tested in that its effects are still evident $18 \mathrm{hr}$. after injection, although most of the drug is known to have been metabolized by then ${ }^{2}$. The survival times of intact controls exposed to cold stress at different times of the day appear to reflect the daily cyclic changes in adrenal activity ${ }^{3}$.

\section{R. Michet Zirberstein*}

Biological Laboratories,

Harvard University, Cambridge, Mass.

* Present address : Straw Road, Hopkinton, N.H., U.S.A.

${ }^{1}$ Shibusawa, K., Saito, S., Fukuda, N., Kawai, T., and Yoshimura, F., Endocrinol. Jap., 2, 47 (1955). "Wells, H., Briggs, F. N., and Munson, P. L., Endocrinol., 60, 571 (1957). Harwood, C. T., and Mason, J., ibid., 60, 239 (1957)

2 Numerof, P., Gordon, M., and Kelly, J. M., J. Pharmacol. and Exp. Therap., i15, 427 (1955).

Vermund, H., Halberg, F., Barnum, C. P., Nash, C. W., and Bittner, J. J., Amer. J. Physiol., 186,444 (1956) Albrecht, P., Visscher, Med., 92, 703 (1956).

\section{Potency of Parenteral Vitamin A}

VITAMrN A is widely employed in clinical practice and is also used extensively as a teratogenic agent for the production and study of fotal abnormalities in laboratory animals ${ }^{\mathbf{x}}$.

Up to the present the customary procedure in experimental work has been for the vitamin to be dissolved in oil and administered orally. This method has a number of disadvantages. In order to ensure that the animal receives the required dose, it is necessary to put the dissolved vitamin directly into the stomach by the somewhat laborious procedure of gastric intubation. Once in the alimentary tract, defects of absorption may lead to the loss of a substantial amount of the vitamin in the fæces. Such defective absorption may be due to the presence of gastric or intestinal inflammatory conditions, to a deficiency in the secretion of bile which leads to a failure in the breakdown of the fat in which the vitamin is dissolved, or to the nature of the oil itself $^{2}$. Some of these factors may also militate against absorption of the vitamin when employed for therapeutic purposes in man.

Subcutaneous or intramuscular injection has many advantages in experimental work from the point of view of convenience and the more precise measurement of dosage, but the results of the injection of oily solutions of vitamin A have been disappointing. Brown and Sturtevant ${ }^{3}$ found that during a 28-day test period little if any benefit resulted from injection and concluded that vitamin $A$ in oil injected subcutane. ously or intramusoularly was utilized to a very small extent if at all. Their conclusions are borne out by the results of experiments which we have carried out in rats. The subcutaneous injection into rats of 60,000 1.U. vitamin A dissolved in arachis oil daily from the eighth to the thirteenth day inclusive of pregnancy did not produce any cleft palates in the young, whereas the same quantities given by gastric intubation over the same period of time resulted in $29 \cdot 7$ per cent of cleft palates in the young. 